\title{
NEWS FEATURE
}




\section{The story of the world's most famous sheep, from the people who brought her to life.}

THE CAST: Karen Walker, embryologist, PPL Therapeutics, Roslin, UK, now director, KXRegulatory, Linlithgow, UK; Bill Ritchie, embryologist, Roslin Institute, now at Roslin Embryology; Angela Scott, cell-culture technician, PPL, now chief operating officer, TC BioPharm, Motherwell, UK; Alan Colman, research director, PPL, now at Harvard University, Cambridge, Massachusetts; Ian Wilmut, embryologist, Roslin, now University of Edinburgh, UK; John Bracken, farm research assistant, Roslin, now retired; Angelika Schnieke, molecular biologist, PPL, now Technical University of Munich, Germany; Harry Griffin, scientific director, Roslin, now retired; Jim McWhir, stem-cell scientist, Roslin, now retired.

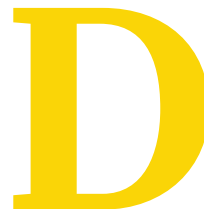

tute, outside Edinburgh, UK.

Karen Walker: On the day we made Dolly, we had such a rubbish day.

Bill Ritchie: It was 8 February 1996. I looked it up. We do know it was a rubbish day: we had various problems with infections and things.

Walker: It's a shame the building has been demolished, otherwise you could see the room in which Dolly was made. I use the word 'room' loosely, because it really was just a big cupboard, which, when Bill and I were in there, you could just get two chairs and the incubator in.

Ritchie: It literally was the cupboard. It was the storage cupboard at the end of the lab. When we got camera crews in later, they couldn't believe it, there was no room to shoot.

Walker and Ritchie were part of a project at the Roslin Institute and spin-off PPL Therapeutics, aiming to make precise genetic changes to farm animals. The scientific team, led by Roslin embryologist lan Wilmut, reasoned that the best way to make these changes would be to tweak the genome of a cell in culture and then transfer the nucleus to a new cell.

Ritchie: The simple way of describing nuclear transfer is that you take an oocyte, an unfertilized egg, and you remove the chromosomes. You then take a complete cell which contains both male and female chromosomes - all of our cells do, apart from the gonads. You take 崖 that cell and fuse it to the enucleated egg, acti골 vate it - which starts it growing - and transfer it to a surrogate mother. Hopefully, with your fingers crossed, you will get a cloned offspring, 岀 a copy of the animal you've taken that cell from.
Walker: Tedious is absolutely the word. You're sitting, looking down a microscope and you've got both hands on the micromanipulators. It's kind of like the joysticks kids use nowadays on games. If your elbow slipped, you could wipe the whole dish out.

A year earlier, the team had produced twin sheep, named Megan and Morag, by cloning cultured embryonic cells in an effort spearheaded by Roslin developmental biologist Keith Campbell. But on this day in February 1996, problems with the fetal cell lines they had planned to use meant that they would need another nuclear donor.

Walker: My memory is of flapping like a chicken, thinking, 'What are we going to put in?' because the cells we were going to use aren't there. The last thing you want to do is waste those oocytes you've got. We wanted to try something, at least.

Angela Scott: I received word from Karen to say that the cells they were expecting had been contaminated. They asked me if I had any cells that they could use. The cells I had were ovine mammary epithelial cells: we were looking to increase expression of proteins in milk. These were adult cells.

Alan Colman: I had come from a background of nuclear transfer with John Gurdon [a developmental biologist at the University of Cambridge, UK]. He'd never been able to get an adult frog by using nuclear transfer from an adult cell donor. He'd been able to get tadpoles using adult cells, but he'd never been able to get an adult frog. I didn't think it would work with adult cells at all. But we had no other cell line to go with, so we all agreed that we'd use these mammary-gland cells ONATURE.COM and just see what hapTowatch an pened, gain some expeinterview with the rience. These were from Dolly team, visit. go.nature.com/28ouboa middle-aged for a sheep.
Ian Wilmut: This is something that is got wrong to this day. Dolly is described as the first mammal cloned from an adult cell. She's actually the first adult clone, period. She's often undersold.

Although cloned and transgenic cows would be more valuable for industry, the Roslin team worked with sheep for practical reasons.

Wilmut: Cattle are incredibly expensive and have a long generation interval. Sheep are much less expensive and much easier to work with. And we knew the reproductive biology. It was very likely that if we could make something work in sheep, it would work in cows. Sheep are small, cheap cows.

John Bracken: There would be 40-60 animals going through surgery [to retrieve oocytes or implant embryos in surrogates] each week during the breeding season. It's a lot of different sheep in the system, and that had to be very accurately monitored so the animals were at the right place at the right time.

Walker: Bill used to keep the embryos and oocytes - when he was bringing them back up from the farm - in his top shirt pocket. I didn't have a top shirt pocket, so I used to tuck them inside my bra. It was a way to keep them warm and fetch them back into the lab and get them into a proper controlled environment. I don't think inside my bra was terribly controlled, but neither was Bill's top shirt pocket.

Ritchie: On the day we made Dolly, I would have done the enucleation, and she would have done the fusion. That was our normal way of doing things.

Walker: I did the fusion on the day we made Dolly. Bill and I joke, that he's the mum and I'm the dad because, essentially, I was the mimic to what the sperm would do.

They transferred 277 nuclei from the mammary cell line - from a white-faced breed known as a Finn Dorset - into eggs from the hardy Scottish blackface breed. Just 29 of the resulting embryos were implanted into surrogate ewes. Expectations were low: it seemed almost impossible that an adult cell nucleus could be reprogrammed to give rise to a live animal. Most cloned embryos aborted, many even before a pregnancy could be determined with ultrasound.

Wilmut: The sheep breeding season begins in October and ends in February, March-ish. By Christmas, we had established pregnancies after transfer from fetal cells, so that was going well. If we hadn't done that, we probably wouldn't have gambled on working with what became Dolly, the mammary cells.

Angelika Schnieke: I remember meeting 
Ian Wilmut in the canteen, and he was very sceptical. He said: "I would be surprised if it works, but PPL is paying for the experiments, so we're doing them."

Bracken: We scanned all the recipients that had embryos transferred, and we knew they were important sheep. Every day that the scientists knew we were scanning, they would be very keen to know if there were any pregnancies.

Walker: I didn't go down to watch all the scans. But with Dolly - because we knew that those were cells Bill and I had put in - I had gone down on that particular day with John.

Bracken: I was just really pleased that it was a pregnancy. I didn't realize the real importance of it because we weren't really told. We just knew it was an important pregnancy. It didn't carry the same weight. We weren't thinking, 'Wow! If this progresses to a live lamb, this is going to be a world beater, or it's going to turn scientific understanding on its head.'

Walker: I'd taken a blank video up with me, so that I could show my colleagues. That video is sitting up in my loft, and to my shame, I have never yet transferred it onto DVD. I should.

Schnieke: I remember the day when we had the first scan. We always asked. And then we saw the picture and the scans. Then you just have to hope that it lasts and goes all the way through.

Wilmut: My memory is they were looking around day 30 or 35 , so there's another 120 days [until the birth], where you keep on sighing with relief and hoping.

Just a few of the team members got to witness her birth.

Bracken: It happened about 4:30 in the afternoon. As soon as she went into labour, we called the Dick Vet [the Royal School of Veterinary Studies in Edinburgh] to get one of their vets to come out. Even though [farm research assistant] Douglas McGavin and myself probably had 50 years of experience between us, it just would have been unheard of if we'd decided we'd assist the birth and something had gone wrong.

Ritchie: We knew Dolly was about to be born, and I think she was showing signs of getting near lambing, and lo and behold I went through and there were bits of Dolly being born. There was a vet there, so she made sure the animal was okay and pulled the lamb out.

Bracken: It was absolutely normal. No complications whatsoever. She was a very viable lamb. She got on her feet very quickly, probably

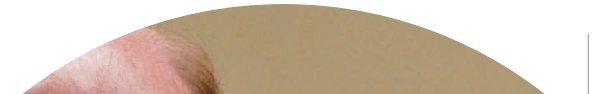

have been a bit worried. With hindsight, without a doubt it was a great name.

Bracken: This is hearsay. I never got told this directly. But I heard they had contacted Dolly Parton and said: "We've got this cloned sheep that's named after you."

Wilmut: I don't know how the message came through, but we were told her agent had said: "There was no such thing as baaad publicity." I don't know if that's true.

Over the next few months, Wilmut's team confirmed that Dolly was a

clone of the mammary cell line, and wrote up the results. Her birth was to be kept top secret, until the Nature paper describing the experiment could be published in February 1997 (I. Wilmut et al. Nature 385, 810-813; 1997).

Harry Griffin: Two or three months before the publication of the paper, I got to know about it. In terms of preparation, PPL were involved. They saw it as an opportunity to get publicity for themselves. We worked with their PR company, De Facto. We did quite a bit of preparation.

Wilmut: Ron James, who was the chief executive of PPL therapeutics, and I were cited as the primary spokesmen and given a bit of training by ex-BBC people, who first of all came up and fairly aggressively stuck microphones up our noses and asked aggressive questions, and subsequently did it very gently. We weren't approached in anywhere near the aggressive way they tried first, which was quite shocking. I'm sure it was worth having.

Ritchie: I think I was jumping up and down when I saw that white face.

Scott: Karen was away at a wedding at the time.

Walker: I had given her the fax number of the hotel. I wish I had kept that fax. It said: "She has a white face and furry legs."

Scott: I don't know what they must have thought at the hotel: "Wow, that's a really unusual baby."

Wilmut: I was in the allotment. I had a phone call to say we had a live lamb. I issued an instruction that nobody should be there who didn't have to be there. Lots were curious. I obeyed my own rule because I'd got nothing to contribute.

Bracken: I'm standing next to Douglas McGavin watching the vet assist this birth, and I made an off-the-cuff remark to Douglas. I said, "You know what we're going to have to call this lamb? We're going to have to call it Dolly", after Dolly Parton, because the cells are derived from mammary tissue.

Wilmut: Being somewhat puritanical, I might
Griffin: We had everything organized. The calls would be directed to De Facto and they would try and organize some coherence in our response in terms of who got priority and who didn't. All this would culminate, we hoped, on the Thursday that the paper came out. What was that, 27 February? Clearly, it didn't.

Wilmut: Robin McKie at The Observer leaked it. He will deny the charge.

Robin McKie, science and technology editor, The Observer, London: I didn't see that stuff in Nature. I don't blame him for being angry, but I went to great pains to avoid the things that would get me to be accused of that. I had helped a couple of guys who were making a TV programme about genetics, and they said, "Oh, by the way, they've cloned a sheep in Edinburgh.” I didn't believe them, but I phoned a few people in the field, and one of them in America confirmed it. But I was very, very worried. I was saying something quite sensational, with absolutely no paper proof of 

Bracken: Away from the media and the cameras, we tried to treat her just like the other sheep, not as a sort of celebrity, which she obviously became.

Walker: The first time she was shorn, they took the wool - which I have some of, actually to be knitted into a jumper for a cystic-fibrosis charity. Have you seen her in the museum? She's behind a glass case now because people kept pinching bits of wool from her. At least I got my wool while she was still alive.

Dolly lived for six and a half years and gave birth to several lambs herself. But in 2003, she began to show signs of illness.

Bracken: It was Valentine's Day. I think it was a Friday. We knew that there was the potential for this lung disease to have developed.

Griffin: She suffered from a disease called jaagsiekte. It's a disease of the lungs and one or two other sheep beforehand had gone down with it.

Wilmut: They thought she should be $X$-rayed over at the vet school. They were surprised at the size of the tumour in her lungs. We debated, under these circumstances, how hard we should struggle for her to recover. Wouldn't it be kinder tojust let her go? So we euthanized her. You are responsible for the welfare of the animals on your project.

A decade later, another loss struck the scientific team with the death of Keith Campbell.

Colman: Keith was the driving force. He was the person who did the important experimental work that sowed the seeds of the protocol we all used. Dolly would not have happened without Keith.

Ritchie: Keith was, I suppose, 'unusual' is probably the thing you would say about him. He was quite hippy. He drove a Volkswagen Beetle, smoked roll-ups, had long hair.

Colman: He didn't have a great relationship with Ian. They were very different personalities and often argued.

Wilmut: I don't remember rows. We would have had slightly different priorities sometimes.

It's always very difficult to divide recognition up. What was obviously the cause of some annoyance and some criticism is that he didn't get the first authorship on the Dolly paper. $\mathrm{He}$ did get absolutely all the others. There was a time when he said the Megan and Morag paper was actually more important than Dolly. $\mathrm{He}$ definitely was frustrated that I got an FRS
(Fellow of the Royal Society) and ultimately a knighthood.

After a domestic dispute, Campbell killed himself on 5 October 2012.

Colman: Keith was a very good friend of mine and we used to go mountain biking in Scotland
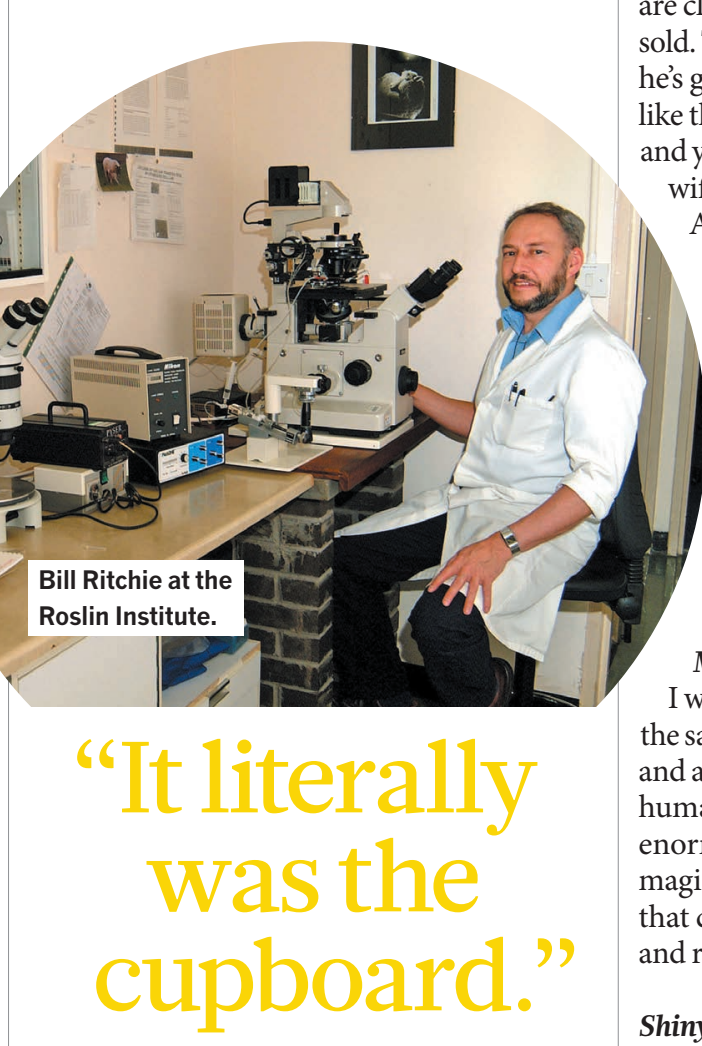

in the evenings after work. I spoke with him three days before he died. I was very shocked.

Walker: That hit me very hard, harder than I would have imagined. I hadn't seen him in many, many years. We were such a close, tight group at the time. We had to be.

Colman: I went to a meeting in Paris last January, where they had a posthumous award. They took a straw poll of how many people in the audience had been helped by what Keith had done, and a huge number of people put their hands up.

The techniques developed in the creation of Dolly were used to copy valuable livestock and make transgenic animals. But in biomedical labs, Dolly hinted at a future in which cells could be reprogrammed to an embryo-like state and used to treat human diseases.

Wilmut: The birth of Dolly turned the rules of development upside down, and made a lot of biologists think differently.

Jeanne Loring, stem-cell biologist, the
Scripps Research Institute, La Jolla, California: That was the onset of cattle cloning, which is actually quite popular now. There's a tremendous value in being able to improve cattle, and this gave people another tool.

George Seidel, animal reproductive biologist, Colorado State University, Fort Collins: There are cloned bulls producing semen that's being sold. There's an Angus bull called Final Answer, he's got half a million offspring or something like that. So his clone is called Final Answer II, and you can buy his semen at half the price. My wife and I have a cattle ranch, so we use Final

Answer II. Hell, it's the same genetics. But from a theoretical standpoint, the transgenic stuff is really much more important than just making copies. To make our first transgenic cow, we created thousands of embryos. It was a huge effort. A tenth of the money, a tenth the animals is what transgenics plus cloning could do for you.

Robert Lanza, chief scientific officer, Astellas Institute for Regenerative Medicine, Marlborough, Massachusetts: I was excited. Now we could hopefully apply the same technique - not so much for animals and agriculture - but for treating a long list of human diseases. What Dolly showed was the enormous power of that technology and the magic of the egg. There were factors in the egg that could take adult cells backwards in time and restore them to an embryonic state.

Shinya Yamanaka, stem-cell scientist, Kyoto University, Japan: My initial response was "Wow! It's like science fiction." But it was not something I was planning to work on. Judging from the paper, the cloning process is very technically challenging. The next year, the first human embryonic-stem-cell paper came out. That's when I re-evaluated Dolly. I thought, at least in theory, we should be able to reprogram somatic cells back into the embryonic state so we can make ES-like stem cells directly from skin or blood cells.

McWhir: A result like Dolly stops people in their tracks, and they say: "Well hang on. If I'd have said that is impossible, what else am I saying is impossible?"

Schnieke: You have some experiments where it brings up your heartbeat. Dolly was one.

Ritchie: It's kind of like having children. I haven't got any myself. Maybe Dolly's that sort of child.

Wilmut: It would be wrong to say my name's known all the way around the world - but Dolly's is.

Ewen Callaway writes for Nature from London. 